\title{
Enzymatic browning and chemical composition of whole yacon [Smallanthus sonchifolius (Poepp.) H. Rob.] tubers as affected by blanching
}

\author{
${ }^{1,2}$ Limbaga, J.C., ${ }^{3}$ Esguerra, E.B. and ${ }^{2 *}$ Castillo-Israel, K.A.T. \\ ${ }^{1}$ Department of Agricultural Sciences, College of Agriculture and Related Sciences, University of \\ Southeastern Philippines, Tagum-Mabini Campus \\ ${ }^{2}$ Institute of Food Science and Technology, College of Agriculture and Food Science, University of the \\ Philippines Los Baños, 4031, College, Laguna \\ ${ }^{3}$ Postharvest Horticulture Training and Research Center, College of Agriculture and Food Science, \\ University of the Philippines Los Baños, 4031, College, Laguna
}

\author{
Article history: \\ Received: 12 March 2020 \\ Received in revised form: 2 \\ May 2020 \\ Accepted: 2 May 2020 \\ Available Online: 13 May \\ 2020
}

\section{Keywords:}

Enzymatic browning,

Yacon,

Blanching,

Polyphenoloxidase,

Fructooligosaccharides

\section{DOI:}

https://doi.org/10.26656/fr.2017.4(5).107

\begin{abstract}
Browning is the major problem associated with yacon [Smallanthus sonchifolius (Poepp.) H. Rob.] processing as it takes place rapidly and intensely after tissue damage. This study investigated the effects of different blanching conditions on the browning parameters and some chemical components of yacon. Whole yacon tubers were blanched in hot water under different temperature and time conditions and immediately cooled in ice water. Increasing blanching temperature and time significantly reduced the polyphenol oxidase (PPO) activity but resulted in an undesirable change in firmness; lightness $\left(\mathrm{L}^{*}\right)$ decreased approaching to a black color flesh of yacon, and the $a^{*}$ and $b^{*}$ values decreased representing a tendency to a green and blue colors, respectively. Blanching the whole yacon at $60^{\circ} \mathrm{C}$ for 20 mins was found to be the most effective and can be used as preprocessing treatment to reduce browning of the product. At this condition, PPO activity was reduced to $70 \%$, firmness was retained, and further browning was decelerated when the cut surface of yacon was allowed to stand at room temperature. Moreover, the total phenolic content (TPC), antioxidant activity, glucose, sucrose and fructose were not significantly different from unblanched yacon but fructooligosaccharide (FOS) content was reduced from 51.36 to $36.29 \%$ on dry weight basis.
\end{abstract}

\section{Introduction}

Yacon [Smallanthus sonchifolius (Poepp.) H. Rob.] is a tuberous root which is rich in fructooligosaccharides (FOS) and insoluble fiber with potential beneficial effects on health. The energy value of the fruit is considered low due to the high water content, around $90 \%$ of its fresh weight. Yacon is also rich in phenolic compounds with strong antioxidant properties (Lachman et al., 2005) which protect the human body from oxidative stress. The antioxidant activity of phenolic compounds is due to their ability to scavenge free radicals, donate hydrogen atoms or electron, or chelate metal ions. The regular consumption of phenolic-rich natural foodstuff has been correlated with reduced risk of occurrence of some kinds of cancer, as well as some inflammatory and cardiovascular disorders. Predominant phenolics in yacon include chlorogenic acid, caffeic acid and ferulic acid. In comparison with other roots and tubers, yacon contains a high level of polyphenols which is approximately $200 \mathrm{mg}$ per $100 \mathrm{~g}$ of fresh weight (Manrique et al., 2005).

However, polyphenols are also substrates for the enzymatic browning of damaged tissues in yacon root, giving it a greenish or black color due to the condensation reaction of polyphenol compounds with amino acids and the enzymatic polymerization of polyphenols (Delgado et al., 2013). In fact, browning is the major problem associated with yacon processing. The enzymatic browning observed in yacon can be considered intense and takes place very rapidly once the tissue is damaged. During the cutting and peeling of yacon, some cell membranes are ruptured, which causes cytoplasmic localizer enzymes (polyphenol oxidases) to come into contact with vacuolar localization substrates (phenols). The polyphenol oxidases (PPO) catalyze the oxidization of the phenols in a process known as 
enzymatic oxidization which results to rapid browning of the freshly cut surface of yacon (Manrique et al., 2005). The common method employed in preventing browning in yacon is the use of chemical agents that are capable of inhibiting the enzymatic reaction. Sodium metabisulfite, ascorbic acid, L-cysteine, citric acid, and tartaric effectively control enzymatic browning in minimally processed yacon (Rodrigues et al., 2013; Vasconcelos et $a l ., 2015)$ and in processing yacon flour (Rodrigues et al., 2014). Another method employed in the inactivation of enzymes responsible for browning is the hot water blanching. Blanching whole yacon can be done as preprocessing treatment to prevent or at least reduce the rapid discoloration of the product. This study aimed to investigate the effects of different blanching parameters on enzymatic browning and chemical composition of yacon and determine the best combination which will result in alleviation of enzymatic browning in yacon.

\section{Materials and methods}

\subsection{Source and preparation of yacon samples}

The newly harvested yacon tubers (yellow-orange colored flesh variety) were obtained from Nueva Viscaya Agricultural Terminal-Agri-Pinoy Trading Center (NVAT-APTC), Bambang, Nueva Viscaya. They were immediately transported by an air-conditioned van to the Institute of Food Science and Technology, UPLB.

\subsection{Treatment and blanching procedure}

Yacon tubers with uniform size and shape were carefully washed with tap water and allowed to dry at room temperature. The yacon tubers were randomly distributed into different treatments. Samples were placed in plastic wire basket and blanched at 40, 50, 60 or $70^{\circ} \mathrm{C}$ for 20,40 or 60 mins using thermostatically controlled water bath using tap water. The blanched samples were immediately cooled for $5 \mathrm{~min}$ in ice water, drained and halved longitudinally and examined for their firmness and color.

\subsection{Polyphenol oxidase extraction and assay}

The crude extract of yacon was obtained by homogenizing $10 \mathrm{~g}$ of frozen yacon with $20 \mathrm{~mL}$ of cold $0.05 \mathrm{M}$ phosphate buffer, $\mathrm{pH} 7$, using a handheld blender for $2 \mathrm{~min}$. The homogenate was immediately filtered through Whatman No. 1 filter paper. The supernatant was collected and used as crude enzyme. All operations were carried on ice.

PPO activity was determined by measuring the rate of increase in absorbance at $420 \mathrm{~nm}$ at $25^{\circ} \mathrm{C}$ using UVVis spectrophotometer. The reaction mixture consisted of $2.9 \mathrm{~mL}$ substrate solution $(0.01 \mathrm{M}$ catechol in $0.1 \mathrm{M}$ phosphate buffer $\mathrm{pH} 7.0$ ) and $0.1 \mathrm{~mL}$ of enzyme solution. The blank sample contained $2.9 \mathrm{~mL}$ substrate solution and $0.1 \mathrm{~mL}$ phosphate buffer. The increase in absorbance at $420 \mathrm{~nm}$ was monitored for 2 mins at $30 \mathrm{~s}$ interval. The linear section of the activity curve as a function of time was used to determine the enzyme activity. Enzymatic activity was expressed in units per gram of fresh matter per minute $\left(\mathrm{U} \cdot \mathrm{g}^{-1} \cdot \mathrm{min}^{-1}\right)$. One unit of PPO activity is defined as the amount of enzyme that caused a change in absorbance of 0.001 O.D. per min. All extracts were analyzed in duplicate. Enzyme activity was calculated as follows (Fernandes et al., 2011):

PPO activity $\left(\mathrm{U} \cdot \mathrm{g}^{-1} \cdot \mathrm{m}^{-1}\right)=\frac{\text { slope }(\mathrm{Abs} / \mathrm{min}) * \text { extract }(\mathrm{mL})}{.001(\mathrm{Abs}) * \text { sample vol. cell }(\mathrm{mL}) * \text { sample weight }(\mathrm{g})}$

\subsection{Firmness}

The firmness of fresh and blanched yacon tubers was measured using handheld penetrometer (IMADA Mechanical Force Gauge Series EM/MF). The penetration was carried out on the midsection and midway between the midsection and the end of the yacon tuber. The yacon was placed in a hard surface and the plunger was inserted into the yacon at uniform force. The depth of penetration was consistent with the scribed line on the tip. The reading was recorded to the nearest $0.5 \mathrm{lb}$ -force.

\subsection{Color assessment of blanched yacon}

Cut yacon surface color was measured randomly at three (3) different points of each of the six yacon samples with chromameter (Konica Minolta Color Reader CR10). Color was recorded using CIE L* $a^{*} b^{*}$. Only $L^{*}, a^{*}$ and $b^{*}$ were considered as these parameters are related to browning. $L^{*}$ indicates lightness, $a^{*}$ indicates chromaticity on a green (-) to red $(+)$ axis, and $b^{*}$ indicates chromaticity on a blue (-) to yellow (+) axis.

To determine the physical indicator of browning, the browning index (BI) based on CIE L* $a^{*} b^{*}$ coordinates was followed and calculated according to the following equation (Palou et al., 1999):

$$
\mathrm{BI}=[100(\mathrm{x}-0.31)] / 0.172
$$

where:

$$
\mathrm{x}=\left(\mathrm{a}^{*}+1.75 \mathrm{~L}^{*}\right) / 5.645 \mathrm{~L}^{*}+\mathrm{a}^{*}-3.012 \mathrm{~b}^{*}
$$

\subsection{Sample preparation for determination of sugars}

Only blanched samples using the most effective time -temperature combination in preventing browning was analyzed for FOS and simple sugars. The method of Muir et al. (2007) was used in the extraction of soluble sugars with slight modification. Samples of yacon tubers were peeled, cut, and homogenized using a blender at high speed for 3-5 mins. Approximately $1 \mathrm{~g}$ sample was weighed into a dry beaker and added with $40 \mathrm{~mL}$ hot 
distilled water $\left(\sim 80^{\circ} \mathrm{C}\right)$. The solution was heated (at $\sim 80^{\circ}$ C) and stirred on a hot-plate with a magnetic stirrer for 15 mins. The solution was cooled to room temperature and then quantitatively transferred into $100 \mathrm{~mL}$ volumetric flask. The volume was adjusted to the mark with distilled water and the contents were mixed thoroughly. An aliquot of the solution was filtered through Whatman No. 1 filter paper. The filtrate was collected in glass vials and stored in the freezer $\left(-20^{\circ} \mathrm{C}\right)$ until analysis of FOS, fructose, glucose, and sucrose.

2.7 Determination of FOS, fructose, glucose, and sucrose contents in yacon tubers

The concentration of FOS was analyzed by the enzymatic spectrophotometric method using Megazyme K-FRUC Kit, Ireland. Fructose, glucose, and sucrose were determined enzymatically using a commercial kit (K-SUFRG Megazyme, Ireland). All reagents were prepared according to the manufacturer's instructions. The procedures suggested by the manufacturer were strictly followed, and the content of individual sugars was calculated and expressed as percentage (\%) dry weight basis.

\subsection{Total phenolic content and antioxidant activity using DPPH assay}

Only blanched samples using the most effective time -temperature combination in preventing browning was analyzed for total phenolic content and antioxidant activity.

To prepare yacon extract, $10 \mathrm{~g}$ of sample was added with $20 \mathrm{~mL} 80 \%$ ethanol and homogenized at high speed for 2 mins using a handheld blender. The homogenate was boiled for $5 \mathrm{~min}$ and then centrifuged for $10 \mathrm{mins}$ at $10,000 \mathrm{rpm}$ at ambient temperature. The filtrate was collected and the remaining phenolics in the residue were extracted using the above method. The filtrate was then pooled and stored at $-20^{\circ} \mathrm{C}$ until analysis of total phenolics and antioxidant activity.

Total phenolic content was determined using the Folin-Ciocalteau method. Yacon extract was diluted by adding $0.9 \mathrm{~mL}$ distilled water to $0.1 \mathrm{~mL}$ yacon extract. Then $2 \mathrm{~mL}$ of $0.25 \mathrm{~N}$ Folin-Ciocalteau phenol reagent was added. The solution was mixed and allowed to stand for 5 mins at room temperature. About $2 \mathrm{~mL}$ of $1 \mathrm{~N}$ $\mathrm{Na}_{2} \mathrm{CO}_{3}$ solution was mixed. The solution was allowed to stand for $1 \mathrm{hr}$ at room temperature in the dark. The absorbance of the final solution was recorded at $640 \mathrm{~nm}$ with respect to the blank solution $(80 \%$ ethanol). Total phenolics were quantified by the calibration curve obtained from measuring the absorbance of known concentrations of Gallic acid standard. The results were expressed as $\mathrm{mg}$ of Gallic acid equivalent per $\mathrm{g}$ of dry weight (mg GAE $\left.\cdot \mathrm{g}^{-1} \mathrm{DW}\right)$.

The DPPH assay was based on the determination of scavenging free 1,1-diphenyl-2-picrylhydrazyl (DPPH) radicals. The method of Castro et al. (2012) with modifications was followed. A DPPH solution was freshly prepared with $2.5 \mathrm{mg}$ of DPPH in $50 \mathrm{~mL}$ absolute ethanol. A blank was prepared by mixing $1 \mathrm{~mL}$ of extraction solvent ( $80 \%$ ethanol) with $1 \mathrm{~mL}$ of DPPH solution. For sample analysis, $1 \mathrm{~mL}$ of the sample extract was mixed with $1 \mathrm{~mL}$ DPPH solution. The reaction was allowed to proceed for $30 \mathrm{mins}$ at room temperature in the dark. The absorbance of the blank (Ao) and the sample extract (As) was measured at $517 \mathrm{~nm}$. The result was expressed in terms of percentage of DPPH reduction or inhibition and was calculated as:

$$
\text { Scavenging effect }(\% \text { inhibition })=\frac{A o-A s}{A o} \times 100
$$

\subsection{Statistical analysis}

Data obtained as a mean of six replications were analyzed by One-way ANOVA in Completely Randomized Design (CRD). Comparison among treatments was done using Tukey's test. Statistical computer software, IBM SPSS Statistics 21, was used.

\section{Results and discussion}

\subsection{Polyphenol oxidase activity}

The rapid browning of the freshly cut surface of yacon tubers can be related to its phenolic compound contents and the activity of the endogenous polyphenol oxidase, the main enzyme involved in enzymatic browning of yacon (Padilha et al., 2009 as cited by Rodrigues et al., 2013). Figure 1 shows the PPO activity during blanching of whole yacon tubers. No significant inactivation of PPO was observed in yacon heated at 40 and $50^{\circ} \mathrm{C}$ for 20 mins when compared to unblanched yacon and it can be seen that slower enzyme inactivation occurred as blanching time progressed. This result indicated that the heat penetration was very slow and the temperature was not enough to inactivate the enzyme. Whereas, greater inactivation of PPO in yacon at higher blanching temperature. At the blanching temperature of $60^{\circ} \mathrm{C}$, there was a rapid decline in enzyme activity after 20 mins blanching and then slowly declined. At $70^{\circ} \mathrm{C}$, $94.85 \%$ of PPO was lost at 20 mins blanching time and showed no significant reduction thereafter. This showed that the temperature required to inactivate the enzyme was already attained in all parts of the yacon.

In the study of Neves and Da Silva (2007), the optimum temperature of the activity of partially purified PPO from yacon tubers was near $30^{\circ} \mathrm{C}$ while the study of Rodrigues et al. (2013) showed that the optimum temperature of crude $\mathrm{PPO}$ was $20^{\circ} \mathrm{C}$. Aside from 
variation on the purity of PPO, the said researchers used different substrates, thus their results on the activity of PPO in yacon were different. Meanwhile, the low temperature blanching of whole potatoes prior to minimal process at $50^{\circ} \mathrm{C}$ for 60 mins reduced the PPO activity by $27-45 \%$ and was found to be effective in preventing browning without loss of firmness and without the appearance of browning on the peel, eyes or infected areas (Yemennicioglu, 2002). Also, in the study of Modler et al. (1993), heating of the whole Jerusalem artichoke tubers prior to processing inactivates polyphenol oxidase.

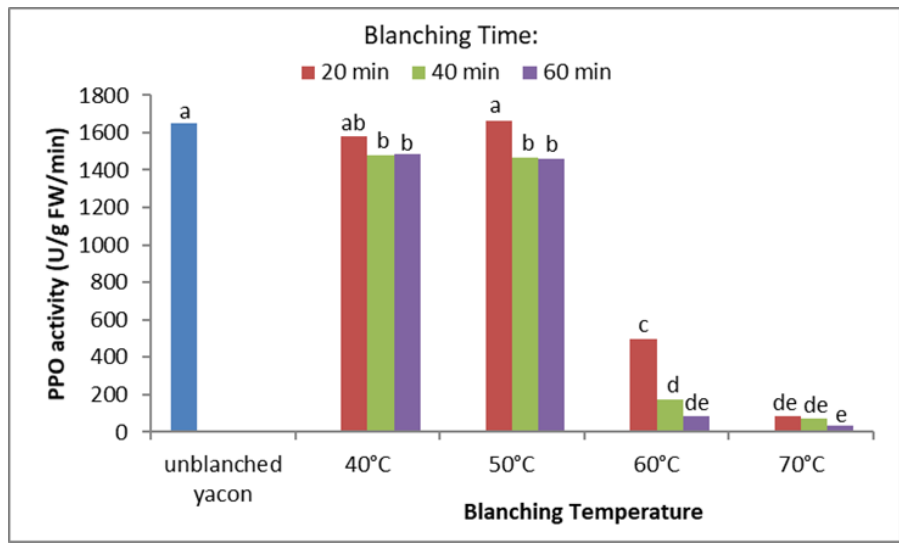

Figure 1. Effects of blanching time and temperature on the PPO activity in yacon. Bars with different letters of the blanching temperature are significantly different based on Tukey's test at $p \leq 0.05$ )

\subsection{Firmness}

The firmness of yacon was significantly affected by blanching at a higher temperature (Figure 2). Generally, the firmness of yacon decreased as temperature and time increased. The most rapid change in firmness occurred at $70^{\circ} \mathrm{C}$, whereby very little change in firmness at $40^{\circ} \mathrm{C}$.

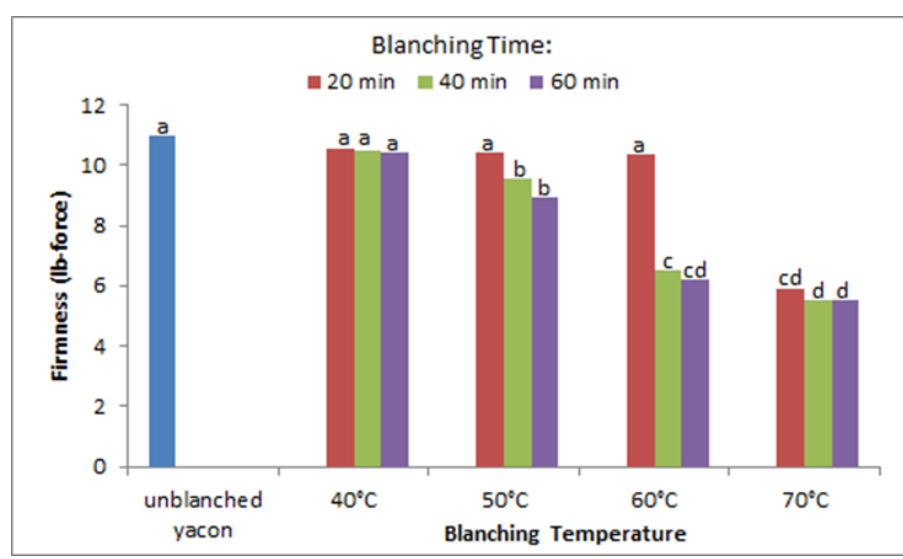

Figure 2. Effects of blanching time and temperature on the firmness of yacon. Bars with different letters of the blanching temperature are significantly different based on Tukey's test at $p \leq 0.05$ )

The firmness of yacon was not statistically affected when blanched at $40^{\circ} \mathrm{C}$ at any duration up to $60 \mathrm{mins}$, whereas a gradual decrease was observed when blanched at $50^{\circ} \mathrm{C}$. No significant difference was observed between and among firmness of unblanched yacon and yacon blanched at $40^{\circ} \mathrm{C}$ for $20-60$ mins, 50 and $60^{\circ} \mathrm{C}$ for 20 mins. On the other hand, an abrupt decrease in firmness occurred after 20 mins blanching at $60^{\circ} \mathrm{C}$ and 20 mins at $70^{\circ} \mathrm{C}$, then no apparent change up to 60 mins blanching time. At these conditions, the yacon tubers were almost cooked.

Over the 60 mins blanching period at $70^{\circ} \mathrm{C}$ there was a $47 \%$ loss in firmness as compared to unblanched yacon, $43 \%$ when blanched at $60^{\circ} \mathrm{C}, 18.45 \%$ when blanched at $50^{\circ} \mathrm{C}$, and $5 \%$ when at blanched at $40^{\circ} \mathrm{C}$. Loss of firmness can be attributed to the loss of turgor pressure and loss of cell wall integrity. During heating, such as blanching, breakdown of cell membrane occurred causing a loss of cell turgor and loss of cell wall integrity caused by loss of pectic compounds (Greve et al., 1994; Llano et al., 2003). The higher the temperature and the longer the blanching time the more damage in the cell membrane, thus the greater loss of firmness.

\subsection{Color change of yacon flesh}

The color parameters were measured immediately after blanching and slicing and then approximately an hour after the treatment to determine if further change in color occurred. The initial parameters $\mathrm{L}^{*}, \mathrm{a}^{*}$ and $\mathrm{b}^{*}$ were $37.54,2.23$ and 18.23, respectively, and the color was light yellow orange. Color parameters of yacon were significantly affected by blanching and continued change in color was observed when the yacon samples were allowed to stand at room temperature for an hour.

Figure 3 shows the effect of blanching on the $\mathrm{L}^{*}$ values of yacon. Blanching at $40^{\circ} \mathrm{C}$ increased the $\mathrm{L}^{*}$ value relative to the unblanched yacon while a decrease in $\mathrm{L}^{*}$ values when blanched at higher temperatures (Figure 3A). This seemed to indicate that yacon color was lighter when blanched at $40^{\circ} \mathrm{C}$ at any length of time than the unblanched, while darker when blanched at 50 , 60 and $70^{\circ} \mathrm{C}$.

The decline in $\mathrm{L}^{*}$ values occurred several minutes after blanching which showed that there was a continuous darkening of samples when allowed to stand at room temperature after blanching and slicing (Figure 3B). Samples blanched at $60^{\circ} \mathrm{C}$ for 40 and 60 mins and at $70^{\circ} \mathrm{C}$ for $20-60$ mins showed a rapid decline in $\mathrm{L}^{*}$ values.

An increase in blanching temperature as well as blanching time caused a significant decline in a* values, demonstrating red color loss. Among the temperatures used in blanching, $40^{\circ} \mathrm{C}$ showed no significant change in $\mathrm{a}^{*}$ values over time, whereas the rapid decline in $\mathrm{a}^{*}$ values occurred at 60 and $70^{\circ} \mathrm{C}$ where the values 
approached towards negative or green color (Figure 4A). The $\mathrm{a}^{*}$ values of blanched yacon at $60^{\circ} \mathrm{C}$ for 40 and 60 mins and those blanched at $70^{\circ} \mathrm{C}$ for $20-60$ mins did not significantly differ from each other.

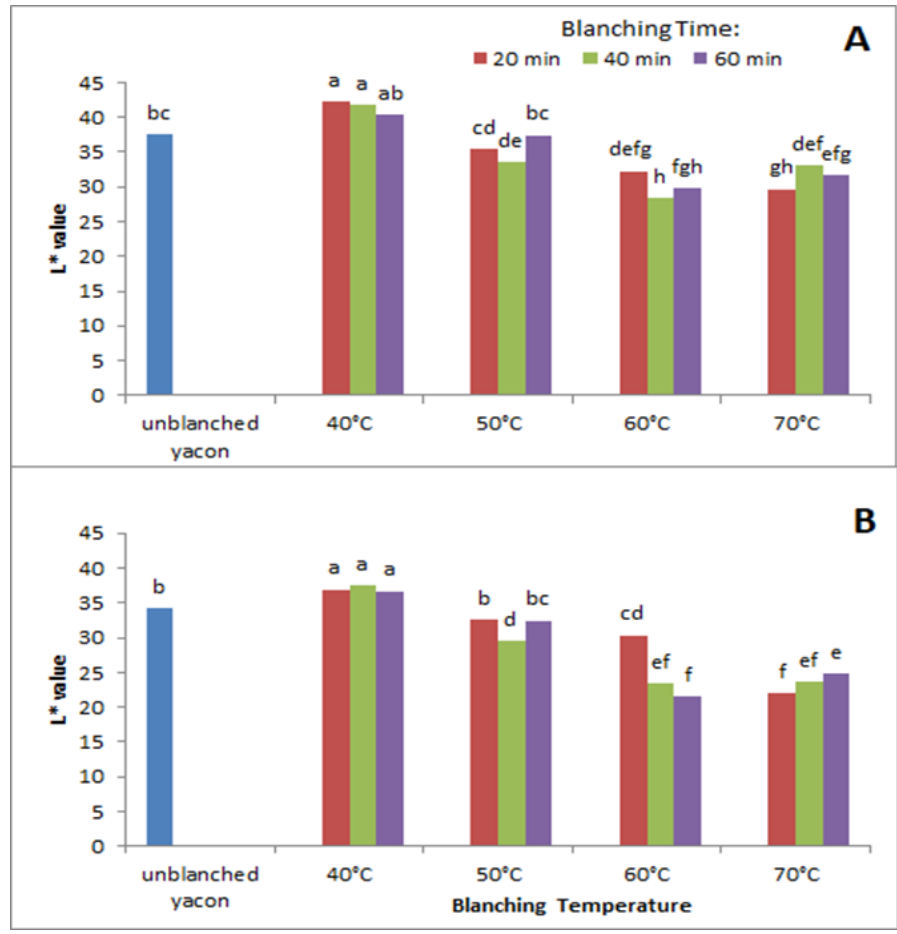

Figure 3. Effects of blanching time and temperature on $\mathrm{L}^{*}$ values of yacon. A: measured immediately after blanching and slicing, B: measured 1 hour after blanching and slicing. Bars with different letters of the blanching temperature are significantly different based on Tukey's test at $p \leq 0.05$ )

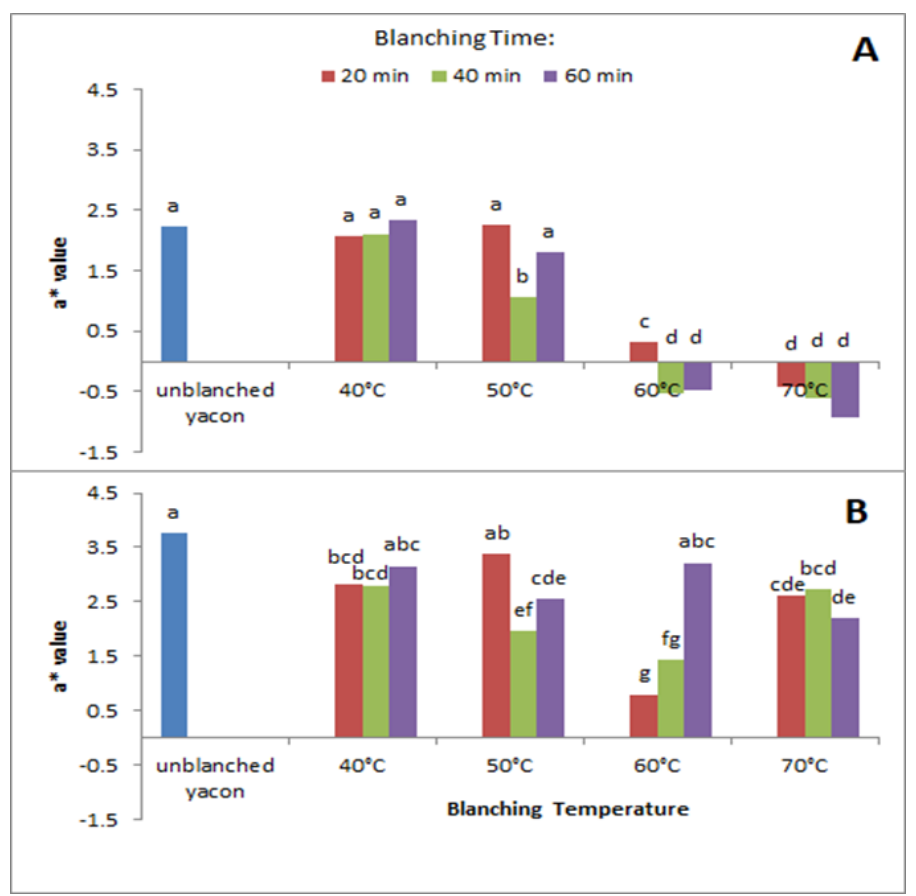

Figure 4. Effects of blanching time and temperature on $\mathrm{a}^{*}$ values of yacon. A: measured immediately after blanching and slicing, B: measured 1 hour after blanching and slicing. Bars with different letters of the blanching temperature are significantly different based on Tukey's test at $p \leq 0.05$ )

On the other hand, when the samples were allowed to stand for $1 \mathrm{hr}$, a* values increased indicating that the samples became reddish (Figure 4B). The greatest increase in $a^{*}$ values several minutes after treatment application was observed on samples blanched at $60^{\circ} \mathrm{C}$ for more than 20 mins and $70^{\circ} \mathrm{C}$ for $20-60$ mins.

For $b^{*}$ values, which indicates the color position between yellow $(+b)$ and blue (-b), significant effects of blanching were observed (Figure 5). There was a decline in $b^{*}$ values as blanching temperature was increased, though the effect of $60^{\circ} \mathrm{C}$ and $70^{\circ} \mathrm{C}$ were similar (Figure $5 \mathrm{~A})$. Increasing the duration of blanching did not affect the $\mathrm{b}^{*}$ values of yacon tubers. Blanching at $40^{\circ} \mathrm{C}$ for 20 60 mins resulted in a slight increase in $b^{*}$ values though not significant, indicating a more yellow color than unblanched yacon. However, as the blanching temperature was increased, a decline in $b^{*}$ values was noted which showed that the color of samples under these treatments was less yellow than the unblanched and those blanched at $40^{\circ} \mathrm{C}$. An increase in $b^{*}$ values was also observed after $1 \mathrm{hr}$ of treatment application (Figure $5 B)$.

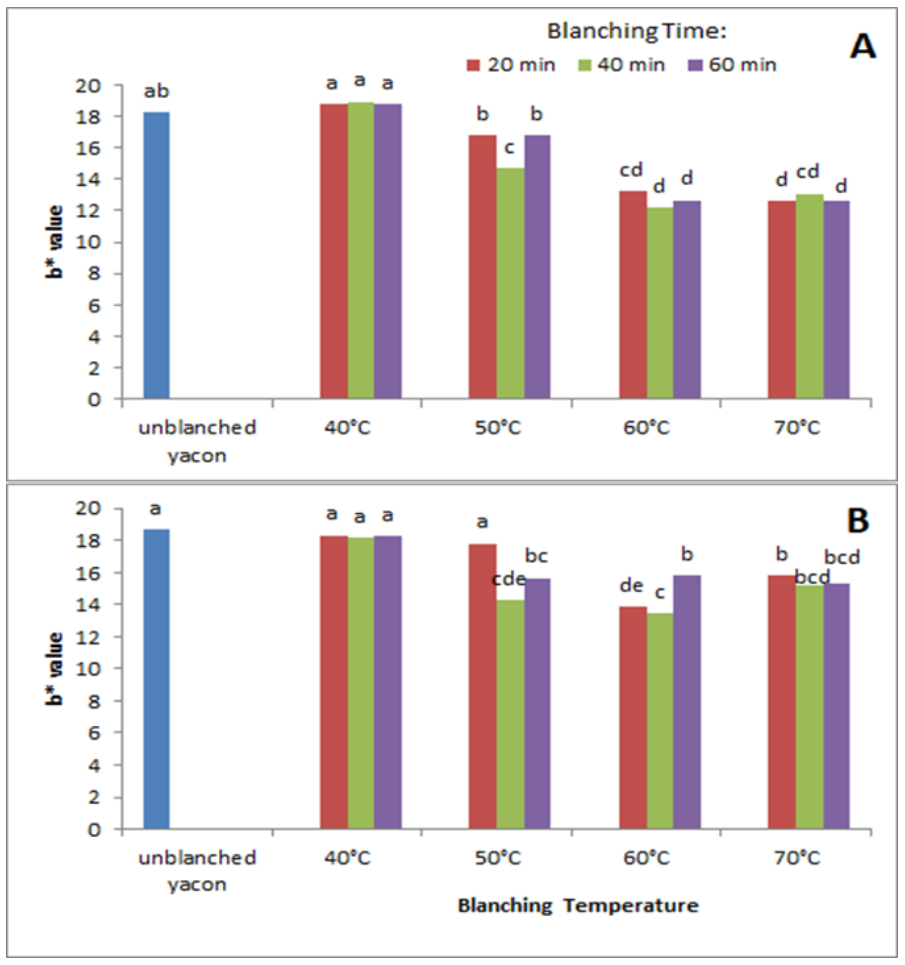

Figure 5. Effects of blanching time and temperature on $b^{*}$ values of yacon. A: measured immediately after blanching and slicing, B: measured 1 hour after blanching and slicing. Bars with different letters of the blanching temperature are significantly different based on Tukey's test at $p \leq 0.05$ )

Yacon samples blanched at $40^{\circ} \mathrm{C}$ have shown little color change with the increase in blanching time while there were more changes in color parameters in the samples blanched at higher temperatures. Generally, a decline in $\mathrm{L}^{*}, \mathrm{a}^{*}$ and $\mathrm{b}^{*}$ occurred as the temperature and duration of blanching increased. The trend of these results was similar to the studies of Goncalves et al. (2007) on blanched pumpkin and Goncalves et al. (2010) on blanched carrots in which they associated the color 
alteration as a result of carotenoid degradation by heat. In the study of Chen (2013), blanching yacon slices changed its color from chalky to a translucent by visual experiment which is somewhat similar to the visual observation of the appearance of yacon tubers in this present study.

The browning index (BI) color parameter is reported by Palou et al. (1999) as an important parameter in processes where enzymatic and non-enzymatic browning takes place. During blanching, it was observed that the browning index $(\mathrm{BI})$ decreased as temperature and time increased. A rapid decline in $\mathrm{BI}$ was observed at $60^{\circ} \mathrm{C}$ and $70^{\circ} \mathrm{C}$ wherein the blanching time at $60^{\circ} \mathrm{C}$ did not differ significantly unlike at $70^{\circ} \mathrm{C}$ (Figure 6A). Browning of fresh yacon occurred immediately after slicing. It can be seen that fresh yacon had the highest BI followed by sample blanched at $40^{\circ} \mathrm{C}$ and $50^{\circ} \mathrm{C}$. At these conditions, PPO activity was highest. On the other hand, the lowest $\mathrm{BI}$ was observed on samples blanched at higher temperatures $\left(60^{\circ} \mathrm{C}\right.$ and $\left.70^{\circ} \mathrm{C}\right)$ where the PPO activity was low. Results also showed that there was a significant positive correlation $\left(\mathrm{R}^{2}=0.891\right)$ between $\mathrm{BI}$ and PPO activity. The higher the PPO activity, the higher was the BI. Thus, the cause of yacon browning in unblanched and those blanched at lower temperatures was mainly due to PPO which catalyzed the oxidation of the phenolic substrates to quinones. In the study of Rodrigues et al. (2013), the optimum temperature for maximum yacon $\mathrm{PPO}$ activity was $20^{\circ} \mathrm{C}$ and the enzyme activity gradually decreased as the temperature increased. They also observed that at $60^{\circ} \mathrm{C}$, approximately $65 \%$ of PPO activity was lost. Whereas, Neves and Da Silva (2007) showed that the optimum temperature of the activity of partially purified PPO from yacon tubers was near $30^{\circ} \mathrm{C}$. In this study, most of PPO activity was not inactivated at $40^{\circ} \mathrm{C}$ and $50^{\circ} \mathrm{C}$ since the whole yacon tubers were used. Perhaps, penetration of heat towards the inner part of the tubers was delayed and the temperature at the center portion of the tubers was not enough to inactivate the enzyme.

Based on the results, blanching reduced the browning of the flesh of yacon, with blanching temperatures of $60^{\circ} \mathrm{C}$ and $70^{\circ} \mathrm{C}$ for a minimum of 20 mins as the most effective. However, after several minutes, discoloration of the samples, including those blanched at lower temperature and the unblanched yacon, was observed. Significant increase in BI was observed when samples were allowed to stand for several minutes at room temperature after the treatment (Figure $6 \mathrm{~B})$. Further browning of the samples could be due to enzymatic or non-enzymatic reactions. Phenolic oxidation mainly includes chemical oxidation and enzymatic oxidation (Dong et al., 2016). The increase in browning of unblanched and blanched yacon at $40^{\circ} \mathrm{C}$ and $50^{\circ} \mathrm{C}$ was probably due to enzymatic oxidation since high PPO activity was present at these conditions in contrast to those blanched at higher temperatures. This condition was also observed by Campos et al. (2016) wherein gradual browning from the external part of the skin towards the center of the yacon slices occurred some hours after blanching in boiling water or steaming for 6 mins. They proposed that this might be due to the higher content of polyphenols present in the skin and the higher content of oxidation catalyzing agents such as $\mathrm{Fe}$ and $\mathrm{Cu}$.

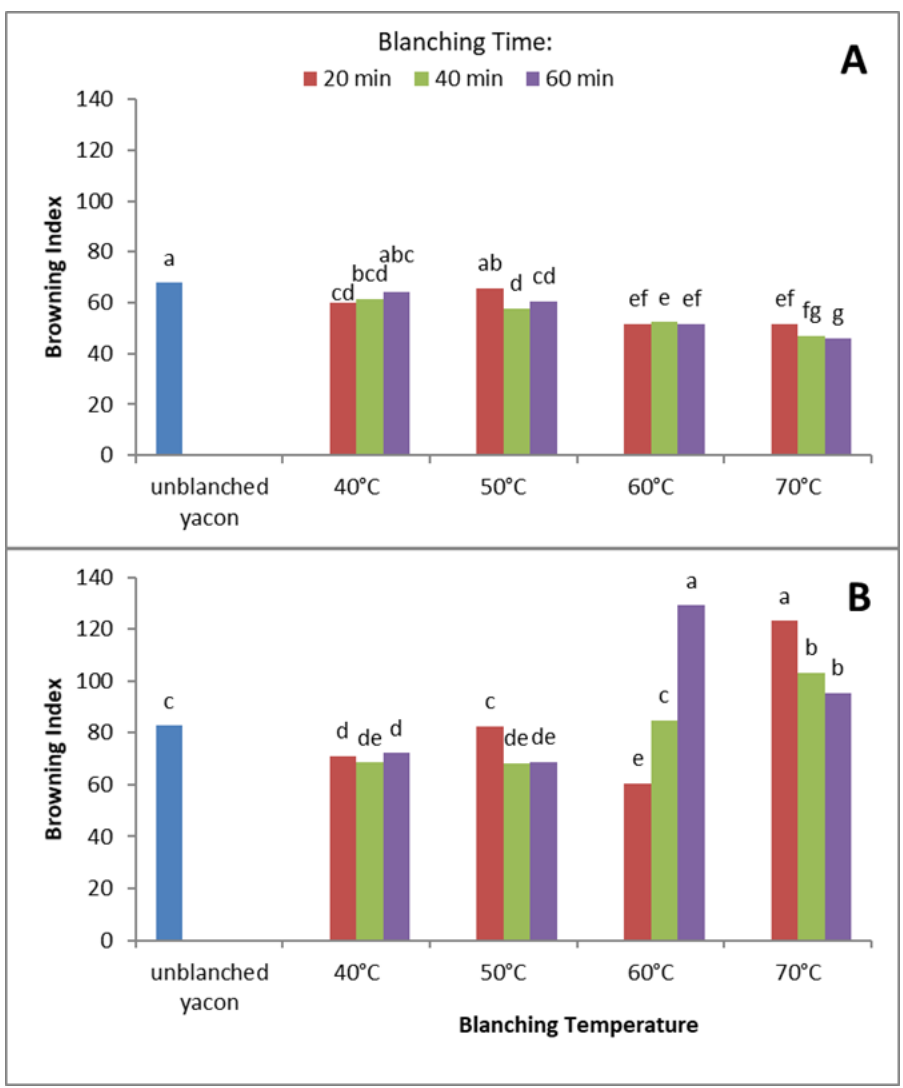

Figure 6. Effects of blanching time and temperature on the browning index of yacon. A: measured immediately after blanching and slicing, B: measured 1 hour after blanching and slicing. Bars with different letters of the blanching temperature are significantly different based on Tukey's test at $p \leq 0.05$ )

In the case of those samples blanched at higher temperatures $\left(60^{\circ} \mathrm{C}\right.$ for more than $20 \mathrm{~min}$ and $70^{\circ} \mathrm{C}$ at all period tested), further browning was not due to enzymatic reaction. This is because PPO activity was lower and the change in BI was higher than those unblanched and blanched samples with higher PPO activity. This could be a non-enzymatic reaction similar to the after-cooking darkening of some varieties of potato. After-cooking darkening occurs when potatoes are exposed to air after cooking (common in boiled or steamed) and are caused by a non-enzymatic oxidation reaction. During cooking, a ferrous-chlorogenic acid complex is formed which, on exposure to air, oxidizes to a bluish-gray compounds ferri-dichlorogenic acid 
(Hughes et al., 1962). Chlorogenic acid is the main phenolic acid in yacon (Lachman et al., 2003; Fernandez et al., 2004) and it contains iron (Pereira et al., 2013), thus after-cooking darkening similar to the potato is possible.

On the bases of PPO inactivation, browning prevention and firmness of yacon, the most effective blanching temperature for the whole yacon was $60^{\circ} \mathrm{C}$ for 20 mins. At this time-temperature combination, there was a $70 \%$ reduction in PPO activity, reduced rapid browning of yacon pulp, and a slight change in firmness with only $6 \%$ reduction. In addition, further discoloration or browning was slowed down when allowed to stand at room temperature.

\subsection{Chemical composition of blanched yacon}

The FOS, simple sugars and total phenolic contents and antioxidant activity of yacon blanched at $60^{\circ} \mathrm{C}$ for 20 mins was determined and compared with the fresh or unblanched yacon to determine if losses of these components occurred during the blanching process.

The result showed that there was a significant reduction in FOS content when the whole yacon tuber was blanched at $60^{\circ} \mathrm{C}$ for 20 mins while no significant changes in glucose, fructose, sucrose, TPC, and antioxidant activity (Table 1). TPC and antioxidant activity of blanched yacon was slightly higher, though not statistically different, than unblanched yacon. TPC was not oxidized during blanching as PPO was inactivated. According to Hwang et al. (2013), phenolic compounds in yacon can be liberated by heat treatment due to the disruption of cell walls and the liberation of soluble phenolic compounds from insoluble ester bonds.

The reduction of FOS content $(29.34 \%$ loss) in the blanched sample could be attributed to leaching of the component into the blanching water and/or hydrolysis of FOS. Some studies reported the decrease in FOS and simple sugars due to leaching during blanching of yacon. Fante et al. (2012) found that yacon slices steam blanched at $100^{\circ} \mathrm{C}$ for 4 min resulted in losses of inulin, glucose and fructose of $30.69,39.40$ and $15.82 \%$, respectively. Scher et al. (2015) showed losses of inulin and reducing sugars occurred during hot water blanching of yacon slices at different time/temperature combinations. However, Fante et al. (2012) mentioned that hydrolysis of inulin may also be related to the residual activity of inulinase or fructan exohydrolase in the blanched samples. Fructan exohydrolase (FEH) was stable up to $40^{\circ} \mathrm{C}$ (Marx et al., 1997; Ueno et al., 2011) and the optimum temperature was $30-40^{\circ} \mathrm{C}$ (Simpson and Bonnet, 1993). To maintain the inulin content, heat treatment processing above $60^{\circ} \mathrm{C}$ has been reported to inactivate inulinase (Takeuchi et al., 2011). In addition, Chen (2013) found lower inulin in blanched yacon slices in water which could be due to leaching and hydrolysis of FOS to reducing sugars. In this present study, the enzymatic hydrolysis could be possible since the temperature was only $60^{\circ} \mathrm{C}$ and the sample used was the whole yacon which slowed the penetration of heat towards the center of the sample, hence FEH was not totally inactivated. Hydrolysis of FOS during blanching could be verified from the non-significant reduction in the simple sugars. If the decline in FOS was only through leaching, glucose, fructose, and sucrose should also decline. Hydrolysis of FOS possibly occurred, producing glucose, fructose, and sucrose and at the same time leaching of these components into the blanching medium.

\section{Conclusion}

Hot water blanching of whole yacon reduced the PPO activity and firmness and changed the color parameters of yacon as temperature and duration of blanching was increased. A decline in $\mathrm{L}^{*}, \mathrm{a}^{*}$ and $\mathrm{b}^{*}$ was observed. Blanching reduced the rapid browning of the cut surface of yacon. Among the temperatures and time used in the study, blanching whole yacon at $60^{\circ} \mathrm{C}$ for 20 mins was found to be the most effective and can be used as pre-processing treatment to reduce browning or discoloration of the yacon flesh during and after processing.

\section{Acknowledgement}

The authors acknowledge the financial support of the Commission on Higher Education - Faculty

Table 1. Comparison of FOS, simple sugars, TPC, and antioxidant activity of unblanched and blanched yacon

\begin{tabular}{lcc}
\hline Parameters & Unblanched Yacon & Blanched Yacon $\left(60^{\circ} \mathrm{C}\right.$ for 20 mins $)$ \\
\hline FOS $(\% \mathrm{DW})$ & $51.36^{*}$ & $36.29^{*}$ \\
Glucose $(\% \mathrm{DW})$ & $15.85^{\mathrm{ns}}$ & $15.70^{\mathrm{ns}}$ \\
Fructose $(\% \mathrm{DW})$ & $23.11^{\mathrm{ns}}$ & $22.30^{\mathrm{ns}}$ \\
Sucrose $(\% \mathrm{DW})$ & $13.53^{\mathrm{ns}}$ & $14.87^{\mathrm{ns}}$ \\
TPC (mg GAE $\cdot \mathrm{g}^{-1}$ sample) & $4.95^{\mathrm{ns}}$ & $5.11^{\mathrm{ns}}$ \\
Antioxidant activity $(\% \mathrm{DPPH}$ inhibition) & $75.42^{\mathrm{ns}}$ & $75.51^{\mathrm{ns}}$ \\
\hline
\end{tabular}

*significant at $\mathrm{p} \leq 0.05$ using $t$-test, ${ }^{\mathrm{ns}}$ not significant 
Development Program (CHED-FDP II) for this research.

\section{References}

Campos, D., Aguilar-Galvez, A. and Pedreschi, R. (2016). Stability of fructooligosaccharides, sugars and color of yacon (Smallanthus sonchifolius) roots during blanching and drying. International Journal of Food Science and Technology, 51(1), 1177-1185. https:// doi.org/ 10.1111/ijfs.13074

Castro, A., Caballero, M., Herbas, A. and Carballo, S. (2012). Antioxidants in yacon products and effect of long-term storage. Ciênciae Technologia de Alimentos, 32(3), 432-435. https:// doi.org/10.1590/ S0101-20612012005000064

Chen, Y.T. (2013). Blanching optimization and the effect of blanching on functional components of yacon (Smallanthus sonchifolius) root slices. USA: Mississippi State University.

Delgado, G., Tamashiro, W., Marostic, M. and Pastore, G. (2013). Yacon (Smallanthus sonchifolius): A Functional Food. Plant Foods for Human Nutrition, 68(3), 222-228. https:// doi.org/10.1007/s11130-0130362-0

Dong, X., Zhang, Y., Wang, F., Pang, M. and Qi, J. (2016). Relationship in between chemical oxidation and browning of flavanols. IOP Conference Series: Earth and Environmental Science, 41(1), 1-9. https:// iopscience.iop.org/1755-1315/41/1/012012

Fante, L., Scher, C.F., Noreña, C. and Rios, A. (2012). Study of enzyme inactivation using steam in yacon (Smallanthus sonchifolius) roots. Journal of Food Processing and Preservation, 37(1), 16-24. https:// doi.org/ 10.1111/j.1745-4549.2011. 00609.x

Fernandes, S.D.S., Ribeiro, C.A.S., Raposo, M.F.J., De Morais, R.M.S.C. and De Morais, A.M.M.B. (2011). Polyphenol oxidase activity and colour changes of 'Starking" apple cubes coated with alginate and dehydrated with air. Food and Nutrition Sciences, 2, 451-457. https:// doi.org/10.423/fns.2011.25064

Fernandez, E.C., Harvland, B., Lachman, J., Hejtmankova, A., Dudjak, J. and Faitova, F. (2004). Content of polyphenol antioxidants and phenolcarboxylic acids in selected organs of yacon [Poster]. Retrieved from: https:// www.researchgate.net/

publication/310169531_Content_of_polyphenolic_a ntioxidants_and_phenolcarboxylic_acids_in_selecte d_organs_of_yacon_Smallanthus_sonchifolius_Poep p_et_Endl_H_Robinson

Goncalves, E.M., Pinheiro, J., Abreu, M., Brandäo, T.R.S. and Silva C.L.M. (2007). Modeling the kinetics of peroxidase inactivation, color and texture changes of pumpkin (Cucurbita maxima L.) during blanching. Journal of Food Engineering, 81(4), 693701. https:// doi.org/10.1016/j.jfoodeng.2007.01.011

Goncalves, E.M., Pinheiro, J., Abreu, M., Brandäo, T.R.S. and Silva C.L.M. (2010). Carrot (Daucus carota L.) peroxidase inactivation, phenolic content and physical changes kinetics due to blanching. Journal of Food Engineering, 97, 74-581. https:// doi.org/10.1016/j.jfoodeng.2009.12.005

Greve, L.C., McArdle, R.N., Gohlke, J.R. and Labavitch, J.M. (1994). Impact of heating on carrot firmness: Changes in cell wall components. Journal of Agricultural and Food Chemistry, 42(12), 29002906. https:// doi.org/10.1021/jf00048a048

Hughes, J.C., Ayers, J.E. and Swain, T. (1962). Aftercooking blackening in potatoes. I.-Introduction and analytical methods. Journal of the Science of Food and Agriculture, 13(4), 224-229. https://doi.org/ $10.1002 /$ jsfa. 2740130403

Hwang I.G., Kim, H.Y., Park, B.R., Han, H.M. and Yoo, S.M. (2013). Effect of heat treatment on the antioxidant properties of yacon (Smallanthus sonchifolius). Korean Journal of Food and Nutrition, 26 (4), 857-864. https://doi.org/10.9799/ ksfan.2013.26.4.857

Lachman, J., Fernandez, E.C. and Orsak, M. (2003). Yacon [Smallanthus sonchifolius (Poepp.Et Endl.) H. Robinson] chemical composition and use - a review. Plant, Soil and Environment, 49(6), 283290. https://doi.org/10.17221/4126-PSE

Lachman, J., Havrland, B., Hejtmánkovál, A. and Fernández, E.C. (2005). Content of polyphenolic antioxidants and phenolic acids in selected parts of yacon (Smallanthus sonchifolius). Scientia Agriculturae Bohemica, 36(2), 49-54.

Llano, K.M., Haedob, A.S., Gerschensona, L.N. and Rojasa, A.M. (2003). Mechanical and biochemical response of kiwifruit tissue to steam blanching. Food Research International, 36(8), 767-775. https:// doi.org/10.1016/S0963-9969(03)00071-1

Manrique, I., Parraga, A. and Hermann, M. (2005). Yacon syrup: Principles and processing. Lima, Peru: Centro International de la Papa (CIP)

Marx, S.P., Nosberger, J. and Frehner, M. (1997). Seasonal variation of fructan- $\beta-(2-1)$ linkage specific FEH from tubers of Jerusalem Artichoke (Helianthus tuberosus). New Phytologist. 135(2), 267-277. https://doi.org/10.1046/j.1469-8137.1997.00641.x

Modler, H.W., Jones, J.D. and Mazza, G. (1993). Observation of long-term storage and processing of Jerusalem artichoke tubers (Helianthus tuberos). Food Chemistry, 48(3), 279-284. https:// 
doi.org/10.1016/0308-8146(93)90141-2

Muir, J.G., Shepherd, S.J., Rosella, O., Rose, R., Barrett, J.S. and Gibson, P.R. (2007). Fructan and free fructose content of common Australian vegetable and fruit. Journal of Agricultural and Food Chemistry, 55(16), 6619-6627. https:// doi.org/10.1021/jf070623x

Neves, V.A. and Da Silva, M.A. (2007). Polyphenol oxidase from yacon roots (Smallanthus sonchifolius). Journal of Agricultural and Food Chemistry, 55(6), 2424-2430. https://doi.org/10.1021/jf063148w

Padilha, V.M., Rolim, P.M., Salgado, S.M., Livera, A.V.S. and Oliveira, M.G. (2009). Tempo de secagem e da atividade de óxido-redutases de yacon (Smallanthus sonchifolius) sob tratamento químico. Ciência Rural, 39(7), 2178-2184. https:// doi.org/10.1590/S0103-84782009005000142

Palou, E., Lopez-Malo, A., Barbosa-Canovas, G.V., Welti-Chanes, J. and Swanson, B.G. (1999). Polyphenoloxidase activity and color of blanched and high hydrostatic pressure treated banana puree. Journal of Food Science, 64(1), 42-45. https:// doi.org/10.1111/j.1365-2621.1999.tb09857.x

Pereira, J.A.R., Barcelos, M.F.P., Pereira, M.C.A. and Ferreira, E.B. (2013). Studies of chemical and enzymatic characteristics of yacon (Smallanthus sonchifolius) and its flours. Food Science and Technology (Campinas), 33(1), 75-83. https:// doi.org/10.1590/S0101-20612013005000020

Rodrigues, M.Z., Martins, E.M.F., Brandao, V.I., Madeira, R.O., Campos, A.N.R. and Ramos, A.M. (2013). Application of antioxidants to extend shelf life of processed minimally yacon (Smallantus sonchifolius). International Journal of Postharvest Technology and Innovation, 3(1), 28-40. https:// doi.org/10.1504/IJPTI.2013.051986

Rodrigues, O. R., Asquieri, E.R. and Orsi, D.C. (2014). Prevention of enzymatic browning of yacon flour by the combined use of anti-browning agents and the study of its chemical composition. Food Science and Technology, 34(2), 275-280. https://doi.org/10.1590/ fst. 2014.0045

Scher, C.F, Brandelli, A. and Noreña, C.Z. (2015.) Yacon inulin leaching during hot water blanching. Ciência e Agrotecnologia, 39(5), 523-529. https:// doi.org/10.1590/S1413-70542015000500011

Simpson, R.G. and Bonnett, G.D. (1993). Fructan exohydrolase from grasses. New Phytologist, 123 (3), 453-469. https://doi.org/10.1111/j.14698137.1993.tb03757.x

Takeuchi, J. and Nagashima, T. (2011). Preparation of dried chips from Jerusalem artichoke (Helianthus tuberosus) tubers and analysis of their functional properties. Food Chemistry, 126(3), 922-926. https://doi.org/10.1016/j.foodchem.2010.11.080

Ueno, K., Ishiguro, Y., Yoshida, M., Onodera, S. and Shiomi, N. (2011). Cloning and functional characterization of fructan 1-exohydrolase (1-FEH) in edible burdock (Arctium lappa L.). Chemistry Central Journal, 5(1), 16. https:// doi.org/10.1186/1752-153X-5-16

Vasconcelos, C.M., De Oliveira, E.B., Rossi, S., Arantes, L., Puschmann, R. and Chaves, J. (2015). Evaluating strategies to control enzymatic browning of minimally processed yacon (Smallanthus sonchifolius). Food and Bioprocess Technology, 8 (9), 1982-1994. https://doi.org/10.1007/s11947-0151558-0

Yemennicioglu, A. (2002). Control of polyphenol oxidase in whole potatoes by low temperature blanching. European Food Research and Technology, 214(4), 313-319. https:// doi.org/10.1007/s00217-001-0442-5 